\title{
Memory Phenotypes of HIV-Specific CD8+ T Cell Responses Are Independent of Functional Activity as Defined by Cytokine Output
}

\author{
Meika E. I. Richmond1, Sandra A. Kiazyk2, Lyle R. McKinnon33, Billy Nyanga4, \\ Charles Wachihi', Makubo Kimani ${ }^{4}$, Joshua Kimani ${ }^{1,4}$, Francis A. Plummer ${ }^{1,4,5}$, \\ T. Blake Ball 1,2,4,5,6* \\ ${ }^{1}$ Department of Medical Microbiology, University of Manitoba, Winnipeg, Canada \\ ${ }^{2}$ National Laboratory for HIV Immunology, National Reference Centre for Mycobacteriology, Public Health \\ Agency of Canada, Winnipeg, Canada \\ ${ }^{3}$ Centre for the Programme of AIDS Research in South Africa, University of KwaZulu-Natal, Durban, South Africa \\ ${ }^{4}$ Department of Medical Microbiology, University of Nairobi, Nairobi, Kenya \\ ${ }^{5}$ National Microbiology Laboratory, Public Health Agency of Canada, Winnipeg, Canada \\ ${ }^{6}$ Department of Immunology, University of Manitoba, Winnipeg, Canada \\ Email: ${ }^{*}$ _ blake ball@phac-aspc.gc.ca
}

Received 19 June 2014; revised 19 July 2014; accepted 19 August 2014

Copyright (C) 2014 by authors and Scientific Research Publishing Inc.

This work is licensed under the Creative Commons Attribution International License (CC BY).

http://creativecommons.org/licenses/by/4.0/

(c) (i) Open Access

\section{Abstract}

Objectives: The definition of CD8+ T cell attributes that mediate protective immunity in HIV disease progression has not been clearly defined. Although our ability to characterize these cells continues to improve, the extent to which specific memory phenotypic categories of CD8+ T cells reliably represent their functional attributes remains controversial. Methods: We simultaneously assessed surface phenotype and functionality of HIV-specific CD8+ T cells by multiparametric flow cytometry, measuring five CD8+ T cell functions (CD107a, IFN $\gamma$, MIP-1 $\beta$, TNF $\alpha$ and IL2) and phenotypic markers CCR7, CD45RA, and CD27, in parallel in 24 HIV-infected individuals. Results: Virus-specific responses were contained within all eight phenotypic categories defined using CCR7, CD45RA, and CD27. Phenotypic profiles of HIV-specific cells differed from CEF-specific cells, with HIV-specific cells having higher levels of CD45RA $(p=0.008)$. Interestingly a large portion of CEF and HIV-specific cells were found within previously undefined phenotypes CCR7+CD27-CD45RA+ (14.6\% and $17.2 \%$, respectively) and CCR7+CD27-CD45RA- (14.8\% and $15.8 \%$, respectively). In addition, up to $10 \%-20 \%$ of responding cells were phenotypically "naive". Additionally, memory phenotypes of cells exhibiting monofunctional and polyfunctional responses frequently differed,

${ }^{*}$ Corresponding author.

How to cite this paper: Richmond, M.E.I., et al. (2014) Memory Phenotypes of HIV-Specific CD8+ T Cell Responses Are Independent of Functional Activity as Defined by Cytokine Output. Open Journal of Immunology, 4, 83-95.

http://dx.doi.org/10.4236/oji.2014.43012 
and failed to associate with a consistent phenotype representing functionally active cells. Conclusion: These data suggest that particularly after antigen stimulation, that surface phenotypes defined by CCR7, CD27 and CD45RA expression on antigen-specific CD8+ T cells, reflect a wide range of immunological functions, and that no single phenotype defined by memory marker expression can reliably be used to identify functional capacity.

\title{
Keywords
}

\author{
CD8+T Cells, HIV, Memory Phenotype, Polyfunctionality, Disease Progression
}

\section{Introduction}

Virus-specific CD8+ T cells are phenotypically and functionally heterogeneous, and a better understanding of specific subsets critical for protective immunity in human immunodeficiency virus (HIV) infection is needed for rationale vaccine design and immune monitoring. With the widespread use of polychromatic flowcytometry, an increasing number of functional parameters of $\mathrm{T}$ cell responses can be assessed simultaneously. These responses comprise a number of functional parameters including cytokine and chemokine expression and cytotoxic markers. An often complementary approach has been the use of surrogate surface phenotypic markers to help define the functional capacity of antiviral $\mathrm{T}$ cells. The most common approach measures the expression of the homing marker CCR7 and the $\mathrm{T}$ cell differentiation marker CD45RA to define cells as central memory $\left(\mathrm{T}_{\mathrm{CM}}\right)$, effector memory $\left(\mathrm{T}_{\mathrm{EM}}\right.$ ), and naive effector [1]-[3]. The addition of CD27 allows further delineation of subsets on the basis of differentiation status, as CD27 is lost upon antigen stimulation [4] [5]. Traditionally, CD8+ T cells expressing CCR7+CD27+CD45RA+ are considered to be functionally naive, while CCR7-CD27-CD45RA+/are functionally active, transiently producing interferon-gamma (IFN $\gamma$ ), and represent terminally differentiated ( $\left.\mathrm{T}_{\mathrm{TD}}\right)$ and $\mathrm{T}_{\mathrm{EM}}$ cell subsets respectively [4]. The phenotype CCR7+CD27+CD45RA- is thought to define a $\mathrm{T}_{\mathrm{CM}}$ subset, which has more long-term functional responses including interleukin-2 (IL2) secretion and proliferative capacity. A transitional memory phenotype (CCR7-CD27+CD45RA-) can also be defined using this model [4].

Although the use of surface markers to define the immunological memory of specific T cells directly ex vivo confers practical advantages, accumulating evidence suggests that these memory markers may not necessarily correspond with the functional capacities they are suggested to represent [6]-[8]. For example, CCR7 expressing memory CD8+ $\mathrm{T}$ cells which are normally considered naive or $\mathrm{T}_{\mathrm{CM}}$, have also been described as having immediate effector functions [9] [10]. Similarly, CD8+ T cells that have proliferative capacity have been found in both CCR7+ and CCR7- subsets, although CCR7- cells are thought to be primarily of the effector phenotype [11]. Studies on CD45RA kinetics reveal that the expression of CD45RA has no correlation to proliferation [12]. This suggests that for memory CD8+ T cells, there are no definitive memory markers that can be used to conclusively identify functional subsets [6]. Our understanding of $\mathrm{T}$ cell differentiation is still limited. Currently, there are three widely accepted models including linear, bifurcative (divergent pathways) and self-renewing differentiation models [13], all of which differ in their definition by surrogate surface memory makers, making their utility to represent $\mathrm{T}$ cell function even more controversial.

Together, these data imply that the surface markers routinely used to define memory $\mathrm{T}$ cells do not necessarily predict the ex vivo function of those cells. However, this has not been well defined for the wide range of polyfunctional CD8+ T cell responses that are now routinely measured. To date, most studies have only used IFN $\gamma$, IL2 expression or proliferative capacity to monitor memory T cell functionality; however polyfunctionality, the concurrent expression of more than one cytokine/chemokine, could play an important role in anti-HIV immunity. HIV infected individuals with slow disease progression (Long-term non-progressors (LTNP), Elite controllers (EC) and Viremic controllers (VC)) have been shown to have increased numbers of polyfunctional HIV-specific CD8+ T cells [14]-[17]. Polyfuntionality is often defined by the concurrent expression of the cytokines IFN $\gamma$, IL-2, and tumor necrosis factor alpha (TNF $\alpha$ ); the chemokine macrophage inflammatory protein 1 beta (MIP$1 \beta$ ); and the degranulation marker CD107a [14]-[16]. These slow progressors also maintain stronger HIV-specific CD8+ T cell proliferative responses compared to normal progressing controls [18]-[21]. Based upon these divergent concepts of functionality versus memory phenotypes, we hypothesized that the surface phenotypes de- 
fined by CCR7, CD45RA, and CD27 will not accurately identify polyfunctional CD8+ T cells. We addressed this hypothesis in a Kenyan cohort of HIV-infected subjects in various stages of HIV disease and treatment. This is the first study to look at the association between function and the dominant paradigm for memory markers in the context of multiparametric cytokine expression, and polyfunctionality.

\section{Methods}

\subsection{Subjects}

HIV-infected female sex workers $(n=24)$ were recruited from a longitudinal cohort based in Nairobi, Kenya [22], and all gave written informed consent prior to their participation in this research. Ethical approval was obtained from relevant review boards at Kenyatta National Hospital/University of Nairobi Ethics and Research Review Committee and the University of Manitoba Health Research Ethics Board, Bannantyne Campus. Clinical and demographic data were collected on subjects biannually; including CD4 T cell counts (Table 1). Antiretroviral therapy (ART) naive subjects with CD4+ counts above $400 \mathrm{cells} / \mu \mathrm{l}$ for over 6 years were classified as long-term non-progressors (LTNP). LTNP were followed for a mean and median years of 11.98 and 14.31 years respectively (range 6.41 - 17.43 years, $n=10$ ). Participants who did not meet the criteria for LTNP were considered to be normal progressors (NP, $n=9$ ), which has been demonstrated to be 3.5 years until AIDS in this cohort [23]. Additionally five subjects on antiretroviral therapy (ART) were included in the study.

Table 1. Clinical and demographic data for subjects in this study.

\begin{tabular}{|c|c|c|c|c|}
\hline Study no. & ART status & Age & Years HIV+ & CD4 count \\
\hline 890 & LTNP & 53 & 16.8 & 570 \\
\hline 1211 & LTNP & 40 & 17.43 & 437 \\
\hline 1250 & LTNP & 49 & 6.41 & 468 \\
\hline 1287 & LTNP & 36 & 6.53 & 547 \\
\hline 1424 & LTNP & 43 & 15.55 & 539 \\
\hline 1625 & LTNP & 43 & 14.37 & 418 \\
\hline 1647 & LTNP & 41 & 13.55 & 731 \\
\hline 1649 & LTNP & 40 & 14.31 & 447 \\
\hline 1654 & LTNP & 36 & 14.31 & 433 \\
\hline 1725 & LTNP & 41 & 10.79 & 452 \\
\hline 1731 & ART & 42 & 13.67 & 228 \\
\hline 1771 & NP & 42 & 12.74 & 186 \\
\hline 1848 & NP & 36 & 10.4 & 184 \\
\hline 1917 & ART & 37 & 7.26 & 456 \\
\hline 1932 & ART & 36 & 6.42 & 407 \\
\hline 1947 & ART & 38 & 6.17 & 359 \\
\hline 1971 & ART & 45 & 5.31 & 168 \\
\hline 1974 & NP & 44 & 5.29 & 235 \\
\hline 2166 & NP & 38 & 4.67 & 233 \\
\hline 2274 & NP & 37 & 1.97 & 921 \\
\hline 2522 & NP & 27 & 0.74 & 408 \\
\hline 2522 & NP & 27 & 0.74 & 408 \\
\hline 2531 & NP & 48 & 0.73 & 256 \\
\hline 2560 & NP & 42 & 0.7 & 446 \\
\hline 2630 & NP & 33 & 0 & 307 \\
\hline
\end{tabular}




\subsection{Reagents}

A peptide library (9 mers overlapping by 8 amino acids) derived from the HIV-1 p24 clade A1 ancestral sequence (Sigma-Genosys) were pooled in a matrix format using Deconvolute This! version 1.0 [24] (courtesy of Mario Roederer, Vaccine Research Center, NIAID, NIH). Clade A1 is the predominant circulating clade in this study population [25]-[27]. Peptide pools were used at $2 \mu \mathrm{g} / \mathrm{ml} /$ peptide, and stimulations were accompanied by 2 positive controls Cytomegolovirus, Epstein-Barr virus and Influenza virus peptides (CEF, 32 peptides/pool, 2 $\mu \mathrm{g} / \mathrm{ml} / \mathrm{peptide}$; AnaSpec) and Staphylococcus aureus enterotoxin B (SEB, $0.1 \mu \mathrm{g} / \mathrm{ml}$; Sigma-Aldrich) and duplicate negative controls consisting of media alone. Monoclonal antibodies for flowcytometry analyses included: CD3-AmCyan, CD8-APCCy7, CCR7-PeCy7, IFN $\gamma$-FITC, CD107a-PeCy5, MIP-1 $\beta$-PE, IL2-APC (BD Biosciences), TNF $\alpha$-Pacific Blue, CD27-Alexa Fluor 700 (eBiosciences) and CD45RA-ECD (Beckman Coulter).

\subsection{Intracellular Cytokine Staining}

Fresh PBMC were isolated by density gradient centrifugation, re-suspended in RPMI 10\% fetal bovine serum (R-10), and stimulated with the HIV-1 p24 peptide pools described above, with each peptide at a concentration of $2 \mu \mathrm{g} / \mathrm{ml} /$ peptide. Pre-titrated amounts of CD107a were added prior to stimulation, as described [14]. After one hour at $37^{\circ} \mathrm{C} 5 \% \mathrm{CO}_{2}$, protein secretion was inhibited by the addition of titrated amounts of Golgi-Plug and Golgi-Stop (BD Biosciences), and incubation was continued for another 13 hours. Cells were then washed, stained for surface marker expression, permeabilized (BD Biosciences), and stained for intracellular markers.

\subsection{Data Acquisition and Analysis}

Cells were analyzed on a LSRII flowcytometer (BD Biosciences). Between 30,000 and 100,000 events were collected within the lymphocyte gate per sample. Data analyses were performed using FlowJo version 9.2 (TreeStar). Boolean gates were applied to the 3 surface markers and the 5 functions and was assessed using SPICE 5.1 (courtesy of Mario Roederer, Vaccine Research Center, NIAID, NIH).

\subsection{Statistical Analysis}

HIV-specific CD8 $+\mathrm{T}$ cell responses were considered positive for a given parameter if they were $\geq 2$-fold higher than the mean of their respective negative controls. Data are reported after background subtraction. Polyfunctional responses were also background subtracted and a lower threshold corresponding to the 90th percentile of distribution of negative values was built for each cytokine pattern and values below this threshold were set to 0 [14]. Statistical analyses were performed using Graph Pad Prism 5.0 and SPICE 5.1. Phenotype comparisons were determined using Wilcoxon matched-pairs and one-way ANOVA Kruskal-Wallis, Post test Dunn's multiple caparisons were also done. Functional correlations were Spearman's rank correlation. Due to the large number of correlations involved, we highlight and report only the most significant and strongest correlations (Those with a threshold for significance of less than $\mathrm{p}=0.001$ (Spearman's rank correlation)).

\section{Results}

\subsection{Phenotype of HIV- and CEF-Specific CD8+ T Cell Responses}

A number of memory $\mathrm{T}$ cell phenotypes have been described, with the dominant paradigm based on CCR7, CD45RA, and CD27 expression [4] [7] [28]. These markers can be used to define 8 phenotypes including naive, central memory, effector memory, transitional memory, and terminally differentiated effector subsets (Table 2) as well as undefined combinations of these markers that have not been examined to date. Following stimulation with HIV-1 p24 peptide pools and a Cytomegalovirus, Epstein barr virus and Influenza virus (CEF) peptide pool we were able to characterize the memory phenotypes of both HIV and CEF specific CD8+ T cells (responding with any single or combination of functions) in HIV-infected subjects using these surface markers. Representative flowcytometry gating is shown in Figure 1.

Overnight HIV p24 and CEF-specific responses were measured in chronically HIV infected subjects $(\mathrm{n}=24)$ using multiple immunological readouts including IFN $\gamma, \operatorname{MIP}-1 \beta, \operatorname{TNF} \alpha, \operatorname{CD} 107 \mathrm{a}$, and IL2 responses. Published previously in Richmond et al. $2012 \mathrm{~J}$. Virology, HIV and CEF-specific responses were detected in the majority of HIV+ subjects [29]. Responding cells were assigned to the 8 phenotypes defined in Table 2 to determine the 
Table 2. Categories of CD8+ T cells on the basis of surface phenotypic marker expression.

\begin{tabular}{|c|c|c|c|c|}
\hline Phenotypic category $^{\mathrm{a}}$ & CCR7 & CD27 & CD45RA & HIV+ \\
\hline naive & + & + & + & $15.6 \%$ \\
\hline Undefined $\# 1^{\mathrm{b}}$ & - & + & + & \\
\hline Undefined \#2 & + & - & + & \\
\hline central memory $\left(\mathrm{T}_{\mathrm{CM}}\right)$ & + & + & - & \\
\hline terminally differentiated $\left(\mathrm{T}_{\mathrm{TD}}\right)$ & - & - & + & $23.1 \%$ \\
\hline transitional memory $\left(\mathrm{T}_{\mathrm{TM}}\right)$ & - & + & - & $13.8 \%$ \\
\hline Undefined \#3 & + & - & - & \\
\hline effector memory $\left(\mathrm{T}_{\mathrm{EM}}\right)$ & - & - & - & $29.5 \%$ \\
\hline
\end{tabular}

${ }^{\mathrm{a}}$ [4] [30] [52]-[56]; ${ }^{\mathrm{b}}$ No phenotypic category has been ascribed to these combinations of markers.

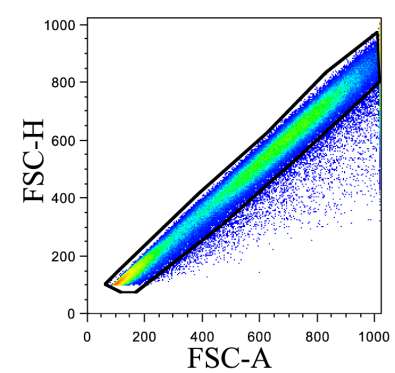

HIV peptide stimulation
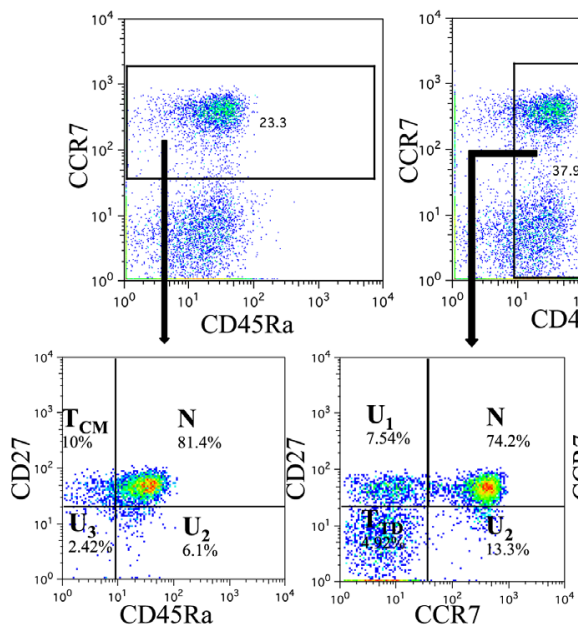

(b)

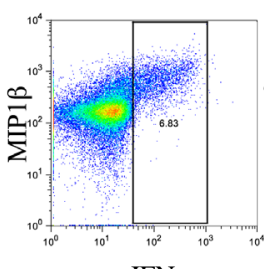

$\mathrm{IFN} \gamma$
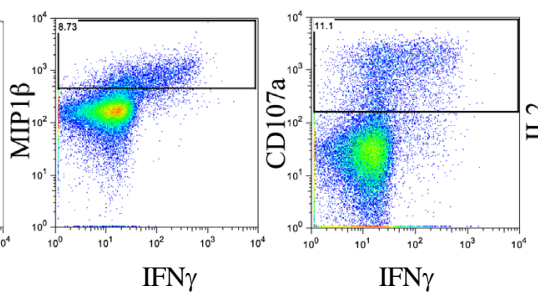

(c)

(a)

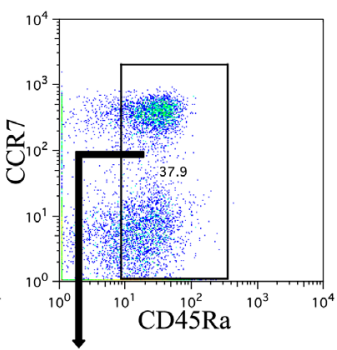

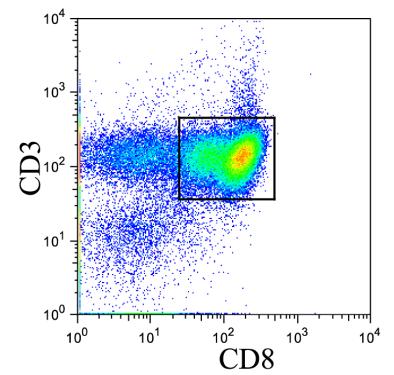
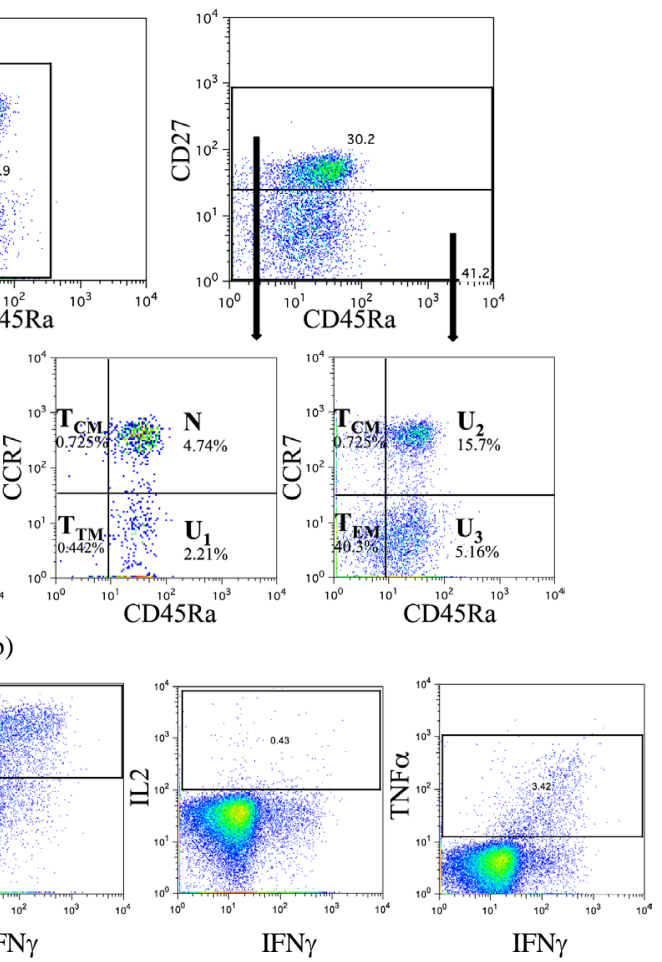

Figure 1. Representative flow cytometry data for detection of polyfunctional CD8+ T cell responses and the definition of CD8+ T cell memory phenotypic categories based on surface marker expression. PBMCs have been stimulated for 14 hours with HIV p24 peptides. (a) Forward scatter area (FSC-A) versus forward scatter height (FSC-H) was used to eliminate doublets. Side scatter area (SSC-A) versus FSC-A was used to identify lymphocytes. (b) After gating on CD3+CD8+ cells, further gates were made for CCR7, CD45Ra and CD27 based on florescence minus one staining. Boolean gating was used to identify dual and triple positive phenotypes. (c) Boolean surface gates were then applied to cells responding with each functional parameter including IFN $\gamma$, MIP-1 $\beta$, CD107a, TNF $\alpha$ and IL2. 
memory phenotypes of HIV and CEF-specific CD8+ T cells. Overall, HIV and CEF-specific antigen responding CD8+ T cells were evenly distributed between 5 of the 8 memory subsets; CCR7+CD27+CD45RA+ (naive), CCR7-CD27-CD45RA+ $\left(\mathrm{T}_{\mathrm{TD}}\right)$, and CCR7-CD27-CD45RA- $\left(\mathrm{T}_{\mathrm{EM}}\right)$, including a substantial number of responses in two novel phenotypes CCR7+CD27-CD45RA+ (Undefined \#2), CCR7+CD27-CD45RA- (Undefined \#3), (Range 14.4\% - 20.5\%, Figure 2(a)) while the remaining three categories CCR7-CD27+CD45RA+ (Undefined \#1), CCR7+CD27+CD45RA- $\left(\mathrm{T}_{\mathrm{CM}}\right)$ and CCR7-CD27+CD45RA- $\left(\mathrm{T}_{\mathrm{TM}}\right)$ were observed less frequently $(<10 \%)$. We then compared the distributions of the various phenotypes between HIV specific and CEF-specific CD8+ T cells. HIV-specific CD8+ T cells were more likely to be CCR7+CD27-CD45RA+ (Undefiend \#2) compared to CEF-specific cells $(\mathrm{p}=0.0012$, mean $17.27 \%$ versus $14.68 \%$, respectively, Wilcoxon matched pairs). This data is in agreement with previous studies that show that different chronic viral infections induce CD8+ T cells with distinct memory phenotypes and functionality [30] [31].

To more clearly understand phenotypic differences observed between HIV and CEF specific CD8 T cells, we compared the expression of each surface marker individually on responding cells (Figure 2(b)). Our data show that CD27 and CCR7 are relatively equally distributed on HIV and CEF specific CD8+ T cells. Both HIV and CEF-specific cells are typically CD27 negative (67.17\% and $67.09 \%$, respectively). There was a modest increase in expression of CD45RA on HIV-specific CD8+ cells compared to CEF-specific CD8+ T cells (54.65\% and $50.96 \%$, respectively, $\mathrm{p}=0.008$ Wilcoxon matched-pairs). These data show that depending on the phenotype CD8+ T cells responding to CEF and HIV antigens may have unique memory phenotypes. However, taken together, both categorical and individual marker data show that there is relatively a homogeneous distribution of virus specific $\mathrm{T}$ cell responses among all the different phenotypic categories of $\mathrm{T}$ cells as defined by CCR7, CD27 and CD45RA, including two previously undefined phenotypes.

\subsection{CD8+ T Cells Expressing Different Functions Have Distinct Memory Phenotypes}

We next determined the surface memory phenotypes of HIV-specific CD8+ T cells expressing each functional parameter individually, independent of expression any other functional readouts (IFN $\gamma$, MIP-1 $\beta$, TNF $\alpha$, CD107a, and IL2). CD8+ T cells positive for each parameter were stratified across the 8 phenotypic categories. Here we observed several functional responses that appear to correlate with the phenotype measured (Figure 3). For example and surprisingly, cells defined as $\mathrm{T}_{\mathrm{EM}}$ were the least likely to be IFN $\gamma$ positive $(\mathrm{p}<0.0001$, Kruskal-Wallis, Post test Dunn's multiple comparison), possibly due to the fact that cells responding with IFN $\gamma$ tended to have higher CCR7 expression, than cells responding with other functional parameters ( $<<0.0001$, data not shown). Each of the phenotypes had a particular functional profile associated with it; the majority of "Undefined \#2"

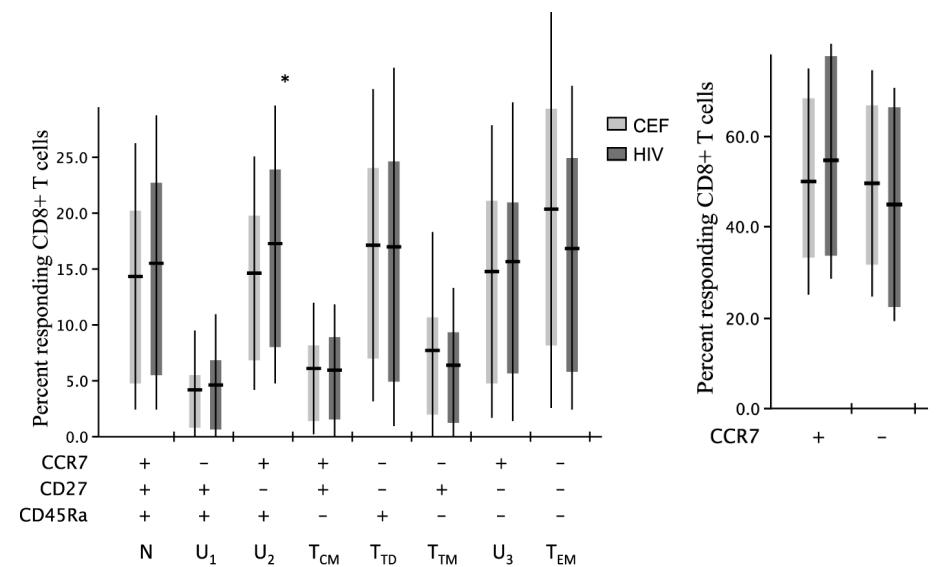

(a)
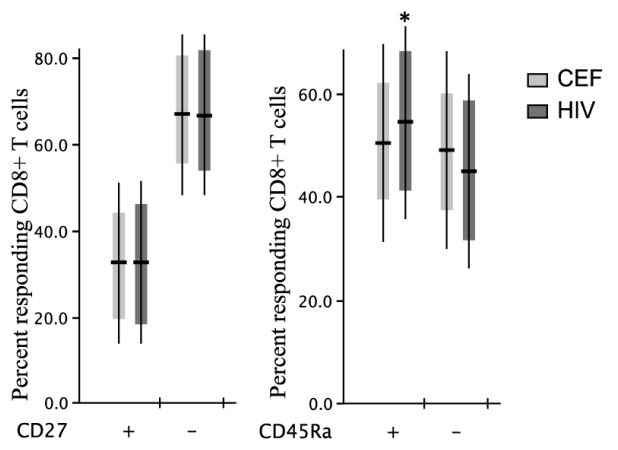

(b)

Figure 2. Expression of eight memory phenotypic categories on CD8+ T cells from HIV-infected subjects. (a) Comparison of all subjects' CEF-specific (light gray bars) and HIV-specific (dark gray bars), positive for any single or combination of cytokine/chemokine function. HIV-specific CD8+ T cells were more likely to be CCR7+CD27-CD45RA+ compared to CEF-specific cells ( $=0.0012$ ); (b) Expression of individual memory surface markers CCR7, CD27 and CD45Ra on CD8+ T cells from HIV-infected subjects, comparison of all subjects' CEF-specific (light gray bars) and HIV-specific (dark gray bars) cytokine/chemokine responses. HIV-specific CD8+ T cells were more likely to be CD45RA+ compared to CEF-specific cells $(p=0.008)$. 


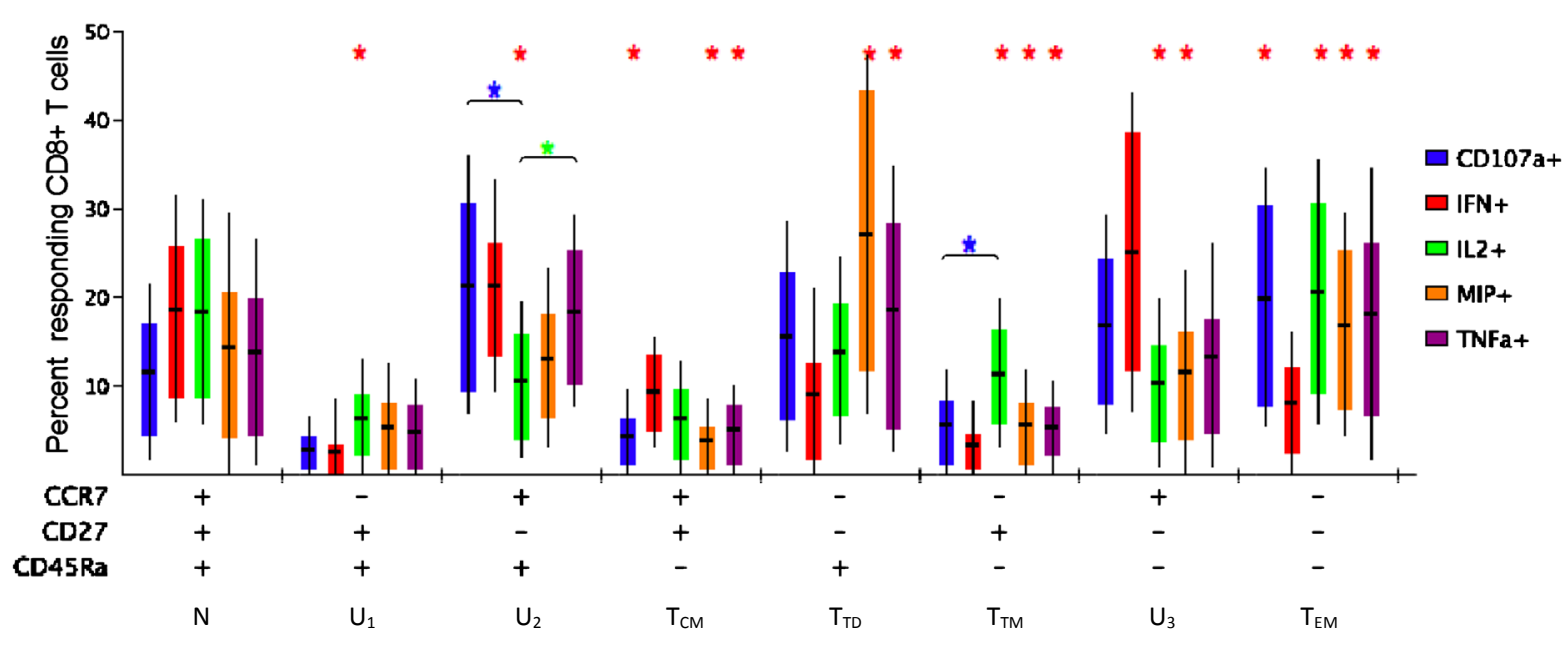

Figure 3. Expression of eight memory phenotypic categories on CD8+ T cells from HIV-infected subjects stratified by individual functional readouts. Functional readouts measured after stimulation with HIV p24 peptides include, CD107a (Blue), IFN $\gamma$ (red), IL2 (green), MIP-1 $\gamma$ (orange) and TNF $\gamma$ (fuchsia). Red asterisk indicates significantly different relative to INF $\gamma$, Blue asterisk indicates significantly different relative to CD107a and green asterisk indicates significantly different relative to IL2 ( $p<0.05$, Wilcoxon matched-pairs).

(CCR7+CD27-CD45RA+) were CD107a and IFN $\gamma$ positive, while $\mathrm{T}_{\mathrm{CM}}$ and Undefined \#3 (CCR7+CD27CD45RA-) were the predominantly expressing IFN $\gamma$. The majority of $\mathrm{T}_{\mathrm{TD}}$ expressed higher MIP- $1 \beta+, \mathrm{T}_{\mathrm{TM}}$ were more often IL2 positive, and $\mathrm{T}_{\mathrm{EM}}$ were most likely to be CD107a and IL2 positive. Interestingly, $10 \%-20 \%$ of responding cells regardless of function could be phenotypically described as naive. Thus, effector function as defined by cytokine responses to HIV appear to be completely independent of, and not predicted by, surface memory phenotype.

To further explore the link between functional parameters and surface phenotypic categories, we next sought to determine if any of the functions correlated with a specific surface phenotype. We correlated the percentage of responding cells for each function with the proportion of overall responding cells contained within each of the 8 phenotypic categories. All functions (CD107a, IFN $\gamma$, MIB- $1 \gamma$ and TNF $\gamma$, excluding IL2) correlated with one or more of the eight memory phenotype categories (Table 3), Both the percentage of cells responding with IFN $\gamma$ and TNF $\alpha$ had similar correlation patterns, consistent with our previous data which found that the expression of IFN $\gamma$ and TNF $\alpha$ are strongly correlated in normal progressing HIV+ subjects [29]. Both were positively associated with the Undefined $\# 2$ and $\mathrm{T}_{\mathrm{CM}}$ phenotypes (All $\mathrm{p}<0.0001$, Spearmen rank correlation), but were inversely correlated to $\mathrm{T}_{\mathrm{TM}}$, Undefined \#3 and $\mathrm{T}_{\mathrm{EM}}$ phenotype $(\mathrm{p}<0.0001, \mathrm{p}<0.0001$ and $\mathrm{p}=0.0002$, respectively). The percentage of cells responding with CD107a was also inversely correlated to the $\mathrm{T}_{\mathrm{EM}}$ phenotype ( $<$ 0.001 ), but positively correlated with Undefined \#1 ( $<<0.001)$. Conversely, the percentage of cells responding with MIP- $1 \beta$ had no similarity to any of the other functions, only correlating with the Undefined \#3 category (p $=0.0005$ ), again consistent with our previous data, which found no correlation between MIP- $1 \beta$ responses and other functions [29]. These data suggest that while some functional attributes do weakly associate with specific "memory phenotypes", this is parameter-specific. These data suggest that the allocation of antigen-specific cells to functional categories on the basis of surface marker expression is exceedingly complex, and varies greatly depending on the functional attribute examined. Thus defining function upon surface phenotype may not be predictable using the markers examined here.

\subsection{Polyfunctionality Does Not Directly Associate with Specific Memory Phenotypes}

The number of functions expressed simultaneously by a single antigen specific cell is increasingly being considered as a correlate of protective immunity in a number of infections [14] [32]-[35]. To determine the surface phenotypes of polyfunctional cells, we stratified our data by CD8+ T cells concurrently expressing increasing numbers of functions $\left(5^{+}, 4+, 3+, 2+\right.$, and $\left.1+\right)$. Polyfunctional responses were observed in all eight memory phenotypic categories, regardless of the number of functions expressed. Figure 4 shows, for each polyfunctional level, the relative proportion of surface phenotypes that account for the response. The percentage of cells 
Table 3. The percentage of cells responding with each function correlated with the proportion of responding cells expressing each of the 8 phenotypic categories.

\begin{tabular}{|c|c|c|c|c|c|c|c|c|}
\hline & $\begin{array}{c}\text { CCR7+CD27 } \\
+ \text { CD45Ra }+ \\
\text { (Naive) }\end{array}$ & $\begin{array}{c}\text { CCR7+CD27 } \\
\text { +CD45Ra- } \\
\text { (Undefined \#1) }\end{array}$ & $\begin{array}{c}\text { CCR7+CD27 } \\
\text {-CD45Ra }+ \\
\text { (Undefined \#2) }\end{array}$ & $\begin{array}{c}\text { CCR7+CD27 } \\
-\mathrm{CD} 45 \mathrm{Ra}^{-} \\
\left(\mathrm{T}_{\mathrm{CM}}\right)\end{array}$ & $\begin{array}{c}\text { CCR7-CD27+ } \\
\text { CD45Ra+ } \\
\left(\mathrm{T}_{\mathrm{TD}}\right)\end{array}$ & $\begin{array}{c}\text { CCR7-CD27+ } \\
\text { CD45Ra- } \\
\left(\mathrm{T}_{\mathrm{TM}}\right)\end{array}$ & $\begin{array}{c}\text { CCR7-CD27 } \\
\text {-CD45Ra }+ \\
\text { (Undefined \#3) }\end{array}$ & $\begin{array}{c}\text { CCR7-CD27 } \\
-\mathrm{CD} 45 \mathrm{Ra}- \\
\left(\mathrm{T}_{\mathrm{EM}}\right)\end{array}$ \\
\hline IFN $\gamma$ & $\mathrm{p}=\mathrm{ns}$ & $\mathrm{p}=\mathrm{ns}$ & $\begin{array}{l}\mathrm{R}=0.3083 \\
\mathrm{p}<0.0001\end{array}$ & $\begin{array}{l}r=0.2923 \\
p<0.0001\end{array}$ & $\mathrm{p}=\mathrm{ns}$ & $\begin{array}{c}r=(-) 0.291 \\
\mathrm{p}<0.0001\end{array}$ & $\begin{array}{c}r=(-) 0.2422 \\
\mathrm{p}<0.0001\end{array}$ & $\begin{array}{c}r=(-) 0.3385 \\
p<0.0001\end{array}$ \\
\hline CD107a & $\mathrm{p}=\mathrm{ns}$ & $\begin{array}{l}r=0.2071 \\
p<0.0001\end{array}$ & $\mathrm{p}=\mathrm{ns}$ & $\mathrm{p}=\mathrm{ns}$ & $\mathrm{p}=\mathrm{ns}$ & $\mathrm{p}=\mathrm{ns}$ & $\mathrm{p}=\mathrm{ns}$ & $\begin{array}{c}r=(-) 0.2168 \\
p<0.0001\end{array}$ \\
\hline IL2 & $\mathrm{p}=\mathrm{ns}$ & $\mathrm{p}=\mathrm{ns}$ & $\mathrm{p}=\mathrm{ns}$ & $\mathrm{p}=\mathrm{ns}$ & $\mathrm{p}=\mathrm{ns}$ & $\mathrm{p}=\mathrm{ns}$ & $\mathrm{p}=\mathrm{ns}$ & $\mathrm{p}=\mathrm{ns}$ \\
\hline MIP- $1 \beta$ & $\mathrm{p}=\mathrm{ns}$ & $\mathrm{p}=\mathrm{ns}$ & $\mathrm{p}=\mathrm{ns}$ & $\mathrm{p}=\mathrm{ns}$ & $\mathrm{p}=\mathrm{ns}$ & $\mathrm{p}=\mathrm{ns}$ & $\begin{array}{l}r=0.1772 \\
p=0.0005\end{array}$ & $\mathrm{p}=\mathrm{ns}$ \\
\hline $\mathrm{TNF} \alpha$ & $\mathrm{p}=\mathrm{ns}$ & $\mathrm{p}=\mathrm{ns}$ & $\begin{array}{l}r=0.2973 \\
p<0.0001\end{array}$ & $\begin{array}{c}r=0.2946 \\
p=<0.0001\end{array}$ & $\begin{array}{c}r=(-) 0.1943 \\
p=0.0001\end{array}$ & $\begin{array}{l}r=(-) 0.2039 \\
p=<0.0001\end{array}$ & $\begin{array}{l}r=(-) 0.2507 \\
p=<0.0001\end{array}$ & $\begin{array}{c}r=(-) 0.1895 \\
p=0.0002\end{array}$ \\
\hline
\end{tabular}

agray and orange shading indicates positive and negative correlations, respectively.

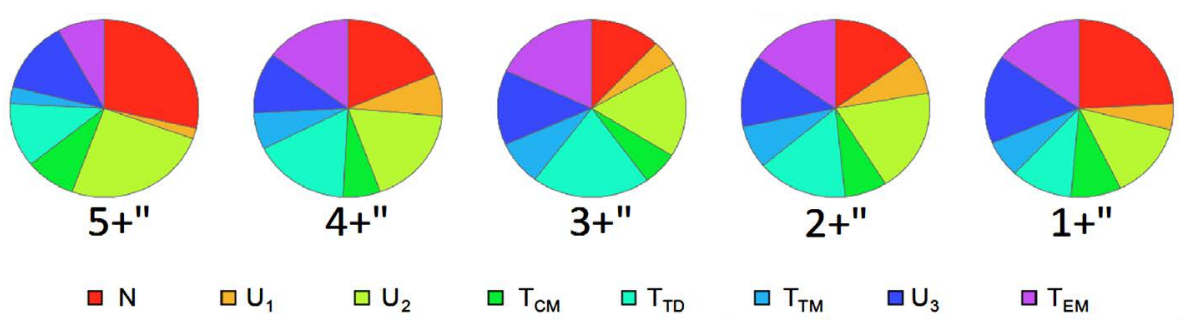

Figure 4. Polyfunctional CD8+ T cell responses stratified by surface phenotype. Pies indicated the relative proportion of each surface phenotype that makes up the polyfunctional response.

responding with each level of polyfunctionality was, than correlated with the proportion of responding cells in each of the 8 phenotypic categories (Table 4). Monofunctional responding cells were associated with the phenotypic categories Undefined \#1, Undefined \#2 and $\mathrm{T}_{\mathrm{CM}}$ (all $\left.\mathrm{p}<0.0001\right)$, but were inversely correlated to $\mathrm{T}_{\mathrm{TM}}$, Undefined \#3 and $\mathrm{T}_{\mathrm{EM}}$ (all $\mathrm{p}<0.0001$ ). Similarly, dual-functional responding cells were inversely correlated to $\mathrm{T}_{\mathrm{TM}}$ and $\mathrm{T}_{\mathrm{EM}}$ (both $\mathrm{p}<0.0001$ ). Cells expressing 3 and 4 functions were positively correlated with the phenotypic category Undefined \#3 ( $\mathrm{p}=0.0004$ and $\mathrm{p}=0.0007$, respectively) while cells expressing 4 and 5 functions were correlated to the phenotype $\mathrm{T}_{\mathrm{TM}}(\mathrm{p}<0.0001$ and $\mathrm{p}=0.0003$, respectively). These data suggest that with increasing expression of multiple functions, the memory surface phenotype is variable. Although most of our data suggests that memory surface markers are unable to predict all functionally active CD8+ T cells, there was a trend towards polyfunctionality associating with the transitional memory phenotypes, $\mathrm{T}_{\mathrm{TM}}$ and Undefiend \#3.

\subsection{Phenotype of HIV and CEF-Specific CD8+ T Cell Responses Stratified by Disease Status}

We finally determined whether HIV and CEF-specific CD8+ T cells differ in their phenotypic distributions on the basis of HIV disease status in this cohort. Participants were separated into normal progressors (NP), longterm non-progressors (LTNP) and patients on ART, to determine phenotypic differences related to disease progression. HIV and CEF-specific CD8+ T cells were assigned to the 8 surface phenotypes (as above). Phenotypic differences were observed in the proportion of responding CD8+ T cells between LTNP, ART or NP subjects, with the LTNPs having a higher proportion of naive, and a lower proportion of $\mathrm{T}_{\mathrm{TD}}$ cells, than NPs and ARTs (Figure 5(a), Figure 5(b), HIV, $p<0.0001$ and $p=0.0094$; and CEF, $p=0.0012$ and $p=0.0074$, respectively, Kruskal-Wallis, Post test Dunn's multiple comparison). These data suggest that the phenotypic changes on CD8+ $\mathrm{T}$ cells following stimulation also differs between clinical groups and viral-specific populations, perhaps due to different activation/stimulation histories.

\section{Discussion}

The complexities of $\mathrm{T}$ cell memory continue to be unraveled by advances in flow cytometry, and these in turn 
Table 4. The percentage of cells responding with each level of polyfunctionality correlated with the proportion of responding cells expressing each of the 8 phenotypic categories.

\begin{tabular}{|c|c|c|c|c|c|c|c|c|}
\hline & $\begin{array}{c}\text { CCR7+CD27 } \\
\text { +CD45Ra+ } \\
\text { (Naive) }\end{array}$ & $\begin{array}{c}\text { CCR7+CD27 } \\
\text { +CD45Ra- } \\
\text { (Undefined \#1) }\end{array}$ & $\begin{array}{c}\text { CCR7+CD27 } \\
\text {-CD45Ra+ } \\
\text { (Undefined \#2) }\end{array}$ & $\begin{array}{c}\text { CCR7+CD27 } \\
\text {-CD45Ra- } \\
\text { (TCM) }\end{array}$ & $\begin{array}{c}\text { CCR7-CD27 } \\
+ \text { D45Ra+ } \\
\text { (TTD) }\end{array}$ & $\begin{array}{c}\text { CCR7-CD27 } \\
+ \text { CD45Ra- } \\
\text { (TTM) }\end{array}$ & $\begin{array}{c}\text { CCR7-CD27 } \\
\text {-CD45Ra+ } \\
\text { (Undefined \#3) }\end{array}$ & $\begin{array}{c}\text { CCR7-CD27 } \\
\text {-CD45Ra- } \\
\text { (TEM) }\end{array}$ \\
\hline $\begin{array}{l}\text { Mono- } \\
\text { functional }\end{array}$ & $\mathrm{p}=\mathrm{ns}$ & $\begin{array}{l}r=0.2698 \\
p<0.0001\end{array}$ & $\begin{array}{l}r=0.3607 \\
p<0.0001\end{array}$ & $\begin{array}{l}r=0.3564 \\
p<0.0001\end{array}$ & $\mathrm{p}=\mathrm{ns}$ & $\begin{array}{c}r=(-) 0.3544 \\
p<0.0001\end{array}$ & $\begin{array}{c}\mathrm{r}=(-) 0.3477 \\
\mathrm{p}<0.0001\end{array}$ & $\begin{array}{c}r=(-) 0.5155 \\
p<0.0001\end{array}$ \\
\hline $2+$ & $\mathrm{p}=\mathrm{ns}$ & $\mathrm{p}=\mathrm{ns}$ & $\mathrm{p}=\mathrm{ns}$ & $\mathrm{p}=\mathrm{ns}$ & $\mathrm{p}=\mathrm{ns}$ & $\begin{array}{c}\mathrm{r}=(-) 0.2535 \\
\mathrm{p}<0.0001\end{array}$ & $\mathrm{p}=\mathrm{ns}$ & $\begin{array}{c}r=(-) 0.2598 \\
p<0.0001\end{array}$ \\
\hline $3+$ & $\mathrm{p}=\mathrm{ns}$ & $\mathrm{p}=\mathrm{ns}$ & $\mathrm{p}=\mathrm{ns}$ & $\mathrm{p}=\mathrm{ns}$ & $\mathrm{p}=\mathrm{ns}$ & $\mathrm{p}=\mathrm{ns}$ & $\begin{array}{l}r=0.1816 \\
p=0.0004\end{array}$ & $\mathrm{p}=\mathrm{ns}$ \\
\hline $4+$ & $\mathrm{p}=\mathrm{ns}$ & $\mathrm{p}=\mathrm{ns}$ & $\mathrm{p}=\mathrm{ns}$ & $\mathrm{p}=\mathrm{ns}$ & $\mathrm{p}=\mathrm{ns}$ & $\begin{array}{l}r=0.1985 \\
p<0.0001\end{array}$ & $\begin{array}{l}r=0.1726 \\
p=0.0007\end{array}$ & $\mathrm{p}=\mathrm{ns}$ \\
\hline $5+$ & $\mathrm{p}=\mathrm{ns}$ & $\mathrm{p}=\mathrm{ns}$ & $\mathrm{p}=\mathrm{ns}$ & $\mathrm{p}=\mathrm{ns}$ & $\mathrm{p}=\mathrm{ns}$ & $\begin{array}{l}r=0.1847 \\
p=0.0003\end{array}$ & $\mathrm{p}=\mathrm{ns}$ & $\mathrm{p}=\mathrm{ns}$ \\
\hline
\end{tabular}

aray and orange shading indicates positive and negative correlations, respectively.

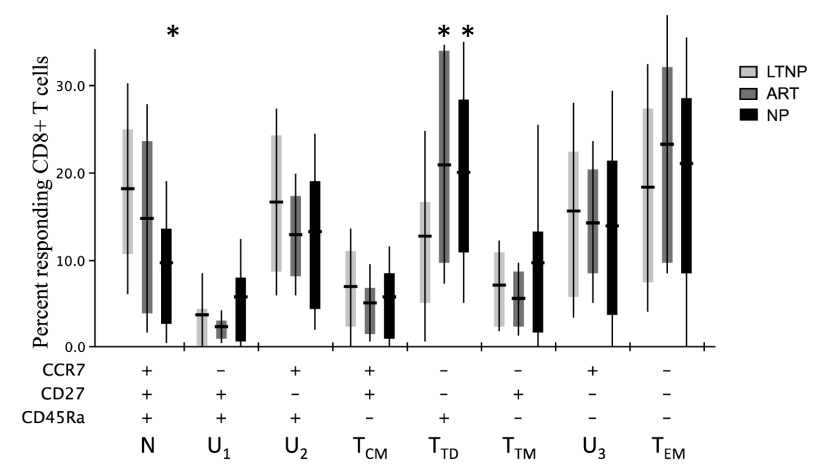

(a)

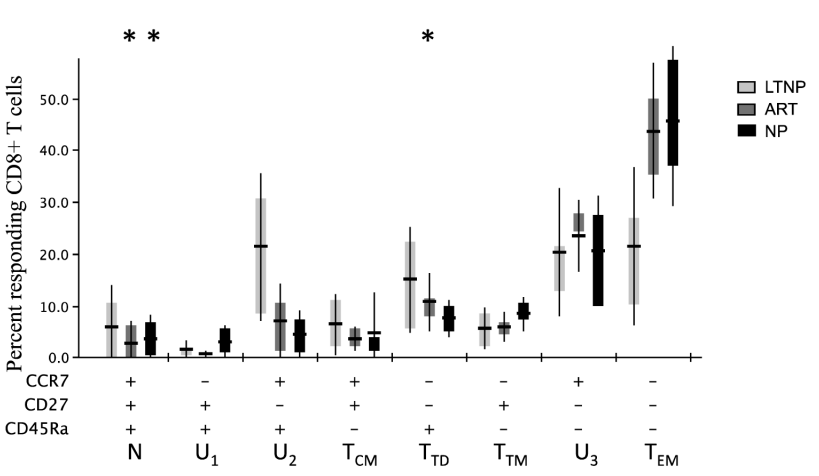

(b)

Figure 5. Expression of eight memory phenotypic categories on CD8+ T cells from HIV-infected subjects stratified by disease status. Comparison of a) HIV-specific b) CEF-specific. An Asterisk indicates significance (ab p $<0.05$, Kruskal-wallis, post test Dunn's multiple comparison).

have implications for understanding protective immunity and candidate vaccine evaluation. Although the use of surface markers to define immunological memory directly ex vivo confers practical advantages, accumulating evidence suggests that these memory markers may not necessarily correspond with the functional capacities that are implied to represent [6]. Here for the first time we present a detailed analysis of the memory phenotypic profiles of HIV and CEF-specific responses and their correlation with specific functional responses in a cohort of chronically infected HIV patients. Chiefly, we find that both HIV and CEF-specific CD8+ T cells responses are observed across all eight phenotypic categories defined by CCR7, CD45RA, and CD27, with naive, $\mathrm{T}_{\mathrm{TD}}, \mathrm{T}_{\mathrm{EM}}$ and two novel phenotypes (CCR7+CD27-CD45RA- (Undefined \#2), and CCR7-CD27-CD45RA+ (Undefined \#3)) that is predominating. Furthermore, the phenotypic profile differed between HIV and CEF antigen-specific cells, with HIV-specific cells expressing higher levels of CD45RA, suggesting a reversion to a more antigen inexperienced state. Interestingly, we observed several differences in phenotypes of individual functional readouts and polyfunctional cells. Each phenotype had a particular function associated with it. For example cells with the $\mathrm{T}_{\mathrm{TD}}$ phenotype, were most likely to express MIP-1 $\beta$ while cells with the Undefined \#3 phenotype, were most likely to express IFN $\gamma$. Additionally, we found no consistent phenotype to represent the totality of functionally active CD8+ T cells. When correlating the proportion of memory phenotypes with the percentage of responding cells regardless of functional parameter, there was no specific phenotype that correlated with all parameters. These data suggest that it remains important to define antiviral $\mathrm{T}$ cells by their functional capacity and that no one phenotype can define that capacity. In addition, correlation of polyfunctional responses revealed that no one-memory phenotype could be associated with all, or even the majority of functional activity. Although there are correlations, suggesting a link between phenotypic markers and particular functions or polyfunctionality, the correlations is not absolute and surface markers cannot be used in place of measuring functionality. Lastly, con- 
firming previous results, LTNPs appear to have an inherent difference in their CD8+ T cell populations, having higher proportions of HIV-specific cells expressing CCR7+CD27-CD45RA+.

A major implication of our data is that surrogate cell surface markers that have been used to define memory phenotypes may not represent the same antigen-specific $\mathrm{T}$ cell populations in all viral infections, populations examined, or even within various disease states. Our study however is the first to comprehensively evaluate memory surface phenotypes in the context of HIV-specific polyfunctional T cell responses, in an unbiased approach evaluating all eight phenotypic categories defined by CCR7, CD45RA, and CD27 including previously "undefined" populations, and the first to examine polyfunctionality in this context. Our data greatly expands previous studies that find inconsistences in the memory surface phenotypes of functional CD8+ T cells [7] [8]. CD8+ T cells that have proliferative capacity have been found in both the CCR7+ and CCR7- subsets [11]. Additionally, CCR7+ and CCR7- memory CD8+ T cells have been described as having immediate effector functions [9] [10]. Similarly, no correlation between CD45RA expression and proliferation potential or IL2 production has been observed [12]. Our comprehensive data confirms that the use of surrogate memory markers to capture the broader array of CD8+ T cells functions and polyfunctionality may be insufficient, particularly in the context of HIV infection.

Determination of function and memory phenotype is particularly critical for understanding the immunology of a chronic infection such as HIV, which skews the naive/memory compartment, and alters many aspects of T cell homeostasis [36]. Clearly a complete understanding of HIV pathogenesis needs to account for these factors. Furthermore, in murine models of chronic viral infection, it is well established that CD8+ T cells are continually recruited as infection progresses [37]-[39]. This is also likely the case for HIV, as CD8+ T cell specificities can change dramatically between acute and chronic infection [40] [41]. Virus-specific CD8+ T cells in chronic infections such as HIV demonstrates substantial functional exhaustion, which occurs in a hierarchical manner as the infection persists and CD8+ T cells become more antigen experienced [33] [42]-[44]. CD8+ T cells in the final stages of exhaustion have lost their polyfunctional quality. This is important information critical to understand both immune factors that affect disease progression, but also to define correlates of protection against HIV disease.

There is a possibility that by taking into account other surface markers that were less focused on memory and more on function, a better definition of effective CD8+ T cells could be gained. These include activation markers, such as CD69, CD38, and HLA-DR [45]; exhaustion markers, such as PD-1 and Tim-3 [46]-[48]; senescence markers such as CD57 [49]; and cellular turnover markers such as Bcl-2 and Ki67 [34]. Moreover, systems biology approaches have revealed a vast number of additional molecules that might together better define the phenotypic state of antigen-specific T cells [50] [51]. Importantly, many of these markers have functional relevance, as opposed to being surrogates of differentiation history such as CCR7, CD27, and CD45RA, which is likely, not completely accurate and further skewed by chronic infection with high antigen load. In summary, these data strongly suggest that CD8+ T cells should be defined by their function rather than surrogate surface markers. Determination of the optimal functional parameters that can be best used to define CD8+ T cells mediating protective immunity remains a primary goal of HIV vaccine evaluation.

\section{Acknowledgments}

We thank the study participants and the staff at the Majengo clinic (1985 to present) and SWOP Clinic (2008 to present) for their dedication and perseverance. We also thank Mario Roederer at the Vaccine Research Center, NIAID, NIH, for providing Deconvolute This! and SPICE software. Thanks to Jennifer Juno for statistical counselling. F.P. is a Tier I Canada Research Chair in susceptibility and resistance to infection.

The MHRC, CIHR, CIHR IID and GH training program and the Government of Canada: Vanier Canadian Graduate Scholarship support M.E.I.R.This work was supported by the Canadian Institute of Health Research HOP 86192

M.E.I.R., L.R.M., S.A.K.K., and T.B.B. conceived and designed the experiments. M.R. B.N. and L.R.M. performed the experiments. M.E.I. R. and L.R.M. analyzed the data. M.E.I.R., L.R.M., S.A.K.K., and T.B.B. wrote the paper. J.K., C.W., M.K., F.A.P., and T.B.B. performed clinical work and cohort maintenance.

\section{References}

[1] Sallusto, F., Lenig, D., Förster, R., Lipp, M. and Lanzavecchia, A. (1999) Two Subsets of Memory T Lymphocytes 
with Distinct Homing Potentials and Effector Functions. Nature, 401, 708-712. http://dx.doi.org/10.1038/44385

[2] Champagne, P., Ogg, G., King, A., Knabenhans, C., Ellefsen, K., Nobile, M., et al. (2001) Skewed Maturation of Memory HIV-Specific CD8 T Lymphocytes. Nature, 410, 106-111. http://dx.doi.org/10.1038/35065118

[3] Mueller, S.N., Gebhardt, T., Carbone, F.R. and Heath, W.R. (2012) Memory T Cell Subsets, Migration Patterns, and Tissue Residence. Annual Review of Immunology, 31, 137-161. http://dx.doi.org/10.1146/annurev-immunol-032712-095954

[4] Chomont, N., El-Far, M., Ancuta, P., Trautmann, L., Procopio, F., Yassine-Diab, B., et al. (2009) HIV Reservoir Size and Persistence Are Driven by T Cell Survival and Homeostatic Proliferation. Nature Medicine, 15, 893-900. http://dx.doi.org/10.1038/nm.1972

[5] van Gisbergen, K.P.J.M., Klarenbeek, P.L., Kragten, N.A.M., Unger, P.-P.A., Nieuwenhuis, M.B.B., Wensveen, F.M., et al. (2011) The Costimulatory Molecule CD27 Maintains Clonally Diverse CD8(+) T Cell Responses of Low Antigen Affinity to Protect against Viral Variants. Immunity, 35, 97-108. http://dx.doi.org/10.1016/j.immuni.2011.04.020

[6] Badovinac, V.P. and Harty, J.T. (2006) Programming, Demarcating, and Manipulating CD8+ T-Cell Memory. Immunological Reviews, 211, 67-80. http://dx.doi.org/10.1111/j.0105-2896.2006.00384.x

[7] Appay, V., Douek, D.C. and Price, D.A. (2008) CD8+ T Cell Efficacy in Vaccination and Disease. Nature Medicine, 14, 623-628. http://dx.doi.org/10.1038/nm.f.1774

[8] Harty, J. and Badovinac, V. (2008) Shaping and Reshaping CD8+ T-Cell Memory. Nature Reviews Immunology, 8, 107-119. http://dx.doi.org/10.1038/nri2251

[9] Unsoeld, H., Krautwald, S., Voehringer, D., Kunzendorf, U. and Pircher, H. (2002) Cutting Edge: CCR7 ${ }^{+}$and CCR7 Memory T Cells Do Not Differ in Immediate Effector Cell Function. The Journal of Immunology, 169, 638-641. http://dx.doi.org/10.4049/jimmunol.169.2.638

[10] Ravkov, E.V., Myrick, C.M. and Altman, J.D. (2003) Immediate Early Effector Functions of Virus-Specific CD8+CCR7+ Memory Cells in Humans Defined by HLA and CC Chemokine Ligand 19 Tetramers. The Journal of Immunology, 170, 2461-2468. http://dx.doi.org/10.4049/jimmunol.170.5.2461

[11] Pitcher, C., Hagen, S., Walker, J., Lum, R., Mitchell, B., Maino, V., et al. (2002) Development and Homeostasis of T Cell Memory in Rhesus macaque. The Journal of Immunology, 168, 29-43. http://dx.doi.org/10.4049/jimmunol.168.1.29

[12] Carrasco, J., Godelaine, D., Van Pel, A., Boon, T. and van der Bruggen, P. (2006) CD45RA on Human CD8 T Cells Is Sensitive to the Time Elapsed since the Last Antigenic Stimulation. Blood, 108, 2897-2905. http://dx.doi.org/10.1182/blood-2005-11-007237

[13] Ahmed, R., Bevan, M., Reiner, S. and Fearon, D. (2009) The Precursors of Memory: Models and Controversies. Nature Reviews Immunology, 9, 662-668. http://dx.doi.org/10.1038/nri2619

[14] Betts, M.R., Nason, M., West, S., De Rosa S., Migueles, S., Abraham J., et al. (2006) HIV Nonprogressors Preferentially Maintain Highly Functional HIV-Specific CD8 ${ }^{+}$T Cells. Blood, 107, 4781-4789. http://dx.doi.org/10.1182/blood-2005-12-4818

[15] Owen, R.E., Heitman, J.W., Hirschkorn, D.F., Lanteri, M.C., Biswas, H.H., Martin, J.N., et al. (2010) HIV+ Elite Controllers Have Low HIV-Specific T-Cell Activation yet Maintain Strong, Polyfunctional T-Cell Responses. AIDS, 24, 1095-1105. http://dx.doi.org/10.1097/QAD.0b013e3283377a1e

[16] Freel, S.A., Lamoreaux, L., Chattopadhyay, P.K., Saunders, K., Zarkowsky, D., Overman, R.G., et al. (2010) Phenotypic and Functional Profile of HIV-Inhibitory CD8 T Cells Elicited by Natural Infection and Heterologous Prime/ Boost Vaccination. Journal of Virology, 84, 4998-5006. http://dx.doi.org/10.1128/JVI.00138-10

[17] Demers, K.R., Reuter, M.A. and Betts, M.R. (2013) CD8 ${ }^{+}$T-Cell Effector Function and Transcriptional Regulation during HIV Pathogenesis. Immunological Reviews, 254, 190-206. http://dx.doi.org/10.1111/imr.12069

[18] Gea-Banacloche, J.C., Migueles, S.A., Martino, L., Shupert, W.L., McNeil, A.C., Sabbaghian, M.S., et al. (2000) Maintenance of Large Numbers of Virus-Specific $\mathrm{CD}^{+} \mathrm{T}$ Cells in HIV-Infected Progressors and Long-Term Nonprogressors. The Journal of Immunology, 165, 1082-1092. http://dx.doi.org/10.4049/jimmunol.165.2.1082

[19] Horton, H., Frank, I., Baydo, R., Jalbert, E., Penn, J., Wilson, S., et al. (2006) Preservation of T Cell Proliferation Restricted by Protective HLA Alleles Is Critical for Immune Control of HIV-1 Infection. The Journal of Immunology, 177, 7406-7415. http://dx.doi.org/10.4049/jimmunol.177.10.7406

[20] Day, C.L., Kiepiela, P., Leslie, A.J., Van Der Stok, M., Nair, K., Ismail, N., et al. (2007) Proliferative Capacity of Epitope-Specific CD8 T-Cell Responses Is Inversely Related to Viral Load in Chronic Human Immunodeficiency Virus Type 1 Infection. Journal of Virology, 81, 434-438. http://dx.doi.org/10.1128/JVI.01754-06

[21] Migueles, S.A., Laborico, A.C., Shupert, W.L., Sabbaghian, M.S., Rabin, R., Hallahan, C.W., et al. (2002) HIV-Specific $\mathrm{CD}^{+} \mathrm{T}$ Cell Proliferation Is Coupled to Perforin Expression and Is Maintained in Nonprogressors. Nature Immunology, 


\section{3, 1061-1068.}

[22] Fowke, K.R., Nagelkerke, N.J., Kimani, J., Simonsen, J.N., Anzala, A.O., Bwayo, J.J., et al. (1996) Resistance to HIV-1 Infection among Persistently Seronegative Prostitutes in Nairobi, Kenya. The Lancet, 348, 1347-1351. http://dx.doi.org/10.1016/S0140-6736(95)12269-2

[23] Anzala, O.A., Nagelkerke, N.J., Bwayo, J.J., Holton, D., Moses, S., Ngugi, E.N., et al. (1995) Rapid Progression to Disease in African Sex Workers with Human Immunodeficiency Virus Type 1 Infection. The Journal of Infectious Diseases, 171, 686-689. http://dx.doi.org/10.1093/infdis/171.3.686

[24] Roederer, M. and Koup, R.A. (2003) Optimized Determination of T Cell Epitope Responses. Journal of Immunological Methods, 274, 221-228. http://dx.doi.org/10.1016/S0022-1759(02)00423-4

[25] Dowling, W., Kim, B., Mason, C., Wasunna, K., Alam, U., Elson, L., et al. (2002) Forty-One Near Full-Length HIV-1 Sequences from Kenya Reveal an Epidemic of Subtype A and A-Containing Recombinants. AIDS, 16, 1809-1820. http://dx.doi.org/10.1097/00002030-200209060-00015

[26] Neilson, J.R., John, G.C., Carr, J.K., Lewis, P., Kreiss, J.K., Jackson, S., et al. (1999) Subtypes of Human Immunodeficiency Virus Type 1 and Disease Stage among Women in Nairobi, Kenya. Journal of Virology, 73, 4393-4403.

[27] Peters, H.O., Mendoza, M.G., Capina, R.E., Luo, M., Mao, X., Gubbins, M., et al. (2008) An Integrative Bioinformatic Approach for Studying Escape Mutations in Human Immunodeficiency Virus Type 1 Gag in the Pumwani Sex Worker Cohort. Journal of Virology, 82, 1980-1992. http://dx.doi.org/10.1128/JVI.02742-06

[28] Takata, H. and Takiguchi, M., (2006) Three Memory Subsets of Human CD8 ${ }^{+}$T Cells Differently Expressing Three Cytolytic Effector Molecules. The Journal of Immunology, 177, 4330-4340. http://dx.doi.org/10.4049/jimmunol.177.7.4330

[29] Richmond, M., Mckinnon, L.R., Kiazyk, S.A.K., Wachihi, C., Kimani, M., Kimani, J., et al. (2011) Epitope Mapping of HIV-Specific CD8 ${ }^{+} \mathrm{T}$ Cell Responses by Multiple Immunological Readouts Reveals Distinct Specificities Defined by Function. Journal of Virology, 85, 1275-1286. http://dx.doi.org/10.1128/JVI.01707-10

[30] Appay, V., Dunbar, P., Callan, M., Klenerman, P., Gillespie, G., Papagno, L., et al. (2002) Memory CD8 ${ }^{+}$T Cells Vary in Differentiation Phenotype in Different Persistent Virus Infections. Nature Medicine, 8, 379-385. http://dx.doi.org/10.1038/nm0402-379

[31] van Baarle, M.D., Kostense, S., van Oers, M.H.J., Hamann, D. and Miedema, F. (2002) Failing Immune Control as a Result of Impaired CD8 ${ }^{+}$T-Cell Maturation: CD27 Might Provide a Clue. Trends in Immunology, 23, 586-591. http://dx.doi.org/10.1016/S1471-4906(02)02326-8

[32] Greene, W.C. and Peterlin, B.M. (2002) Charting HIV's Remarkable Voyage through the Cell: Basic Science as a Passport to Future Therapy. Nature Medicine, 8, 673-680. http://dx.doi.org/10.1038/nm0702-673

[33] Decrion, A., Varin, A., Drobacheff, C., Estavoyer, J. and Herbein, G. (2007) A Subset of Functional Effector-Memory $\mathrm{CD}^{+} \mathrm{T}$ Lymphocytes in Human Immunodeficiency Virus-Infected Patients. Immunology, 121, 405-415. http://dx.doi.org/10.1111/j.1365-2567.2007.02589.x

[34] Stevenson, M. (2003) HIV-1 Pathogenesis. Nature Medicine, 9, 853-860.

[35] Burgers, W., Riou, C., Mlotshwa, M., Maenetje, P., de Assis Rosa, D., Brenchley, J., et al. (2009) Association of HIVSpecific and Total CD8 ${ }^{+}$T Memory Phenotypes in Subtype C HIV-1 Infection with Viral Set Point. The Journal of Immunology, 182, 4751-4761. http://dx.doi.org/10.4049/jimmunol.0803801

[36] Ganesan, A., Chattopadhyay, P., Brodie, T., Qin, J., Gu, W., Mascola, J., et al. (2010) Immunologic and Virologic Events in Early HIV Infection Predict Subsequent Rate of Progression. The Journal of Infectious Diseases, 201, 272-284. http://dx.doi.org/10.1086/649430

[37] Seder, R., Darrah, P. and Roederer, M. (2008) T-Cell Quality in Memory and Protection: Implications for Vaccine Design. Nature Reviews Immunology, 8, 247-258. http://dx.doi.org/10.1038/nri2274

[38] Streeck, H., Brumme, Z.L., Anastario, M., Cohen, K.W., Jolin, J.S., Meier, A., et al. (2008)Antigen Load and Viral Sequence Diversification Determine the Functional Profile of HIV-1-Specific CD8 ${ }^{+}$T Cells. PLoS Medicine, 5, e100. http://dx.doi.org/10.1371/journal.pmed.0050100

[39] Miller, J., van der Most, R., Akondy, R., Glidewell, J., Albott, S., Masopust, D., et al. (2008) Human Effector and Memory CD8 ${ }^{+}$T Cell Responses to Smallpox and Yellow Fever Vaccines. Immunity, 28, 710-722.

[40] Duvall, M., Precopio, M., Ambrozak, D., Jaye, A., McMichael, A., Whittle, H., et al. (2008) Polyfunctional T Cell Responses Are a Hallmark of HIV-2 Infection. European Journal of Immunology, 38, 350-363. http://dx.doi.org/10.1002/eji.200737768

[41] Kiazyk, S.A.K. and Fowke, K.R. (2008) Loss of CD127 Expression Links Immune Activation and CD4 ${ }^{+}$T Cell Loss in HIV Infection. Trends in Microbiology, 16, 567-573. http://dx.doi.org/10.1016/j.tim.2008.08.011

[42] Klenerman, P. and Hill, A. (2005) T Cells and Viral Persistence: Lessons from Diverse Infections. Nature Immunology, 6, 
873-879. http://dx.doi.org/10.1038/ni1241

[43] Vezys, V., Masopust, D., Kemball, C.C., Barber, D.L., O’Mara, L.A., Larsen, C.P., et al. (2006) Continuous Recruitment of Naive T Cells Contributes to Heterogeneity of Antiviral CD8 T Cells during Persistent Infection. Journal of Experimental Medicine, 203, 2263-2269. http://dx.doi.org/10.1084/jem.20060995

[44] Allen, T., Yu, X., Kalife, E., Reyor, L., Lichterfeld, M., John, M., et al. (2005) De Novo Generation of Escape Variant-Specific CD8 ${ }^{+}$T-Cell Responses Following Cytotoxic T-Lymphocyte Escape in Chronic Human Immunodeficiency Virus Type 1 Infection. Journal of Virology, 79, 12952-12960. http://dx.doi.org/10.1128/JVI.79.20.12952-12960.2005

[45] Goulder, P.J., Altfeld, M.A., Rosenberg, E.S., Nguyen, T., Tang, Y., Eldridge, R.L., et al. (2001) Substantial Differences in Specificity of HIV-Specific Cytotoxic T Cells in Acute and Chronic HIV Infection. The Journal of Experimental Medicine, 193, 181-194. http://dx.doi.org/10.1084/jem.193.2.181

[46] Streeck, H., Jolin, J.S., Qi, Y., Yassine-Diab, B., Johnson, R.C., Kwon, D.S., et al. (2009) Human Immunodeficiency Virus Type 1-Specific CD8 ${ }^{+}$T-Cell Responses during Primary Infection Are Major Determinants of the Viral Set Point and Loss of CD4 ${ }^{+}$T Cells. Journal of Virology, 83, 7641-7648. http://dx.doi.org/10.1128/JVI.00182-09

[47] Shin, H. and Wherry, E. (2007) CD8 T Cell Dysfunction during Chronic Viral Infection. Current Opinion in Immunology, 19, 408-415. http://dx.doi.org/10.1016/j.coi.2007.06.004

[48] Wherry, E., Blattman, J., Murali-Krishna, K., van der Most, R. and Ahmed, R. (2003) Viral Persistence Alters CD8 T-Cell Immunodominance and Tissue Distribution and Results in Distinct Stages of Functional Impairment. Journal of Virology, 77, 4911-4927. http://dx.doi.org/10.1128/JVI.77.8.4911-4927.2003

[49] Kristensen, N., Christensen, J. and Thomsen, A. (2002) High Numbers of IL-2-Producing CD8 ${ }^{+}$T Cells during Viral Infection: Correlation with Stable Memory Development. Journal of General Virology, 83, 2123-2133.

[50] Hikono, H., Kohlmeier, J.E., Takamura, S., Wittmer, S.T., Roberts, A.D. and Woodland, D.L. (2007) Activation Phenotype, Rather than Central- or Effector-Memory Phenotype, Predicts the Recall Efficacy of Memory CD8 ${ }^{+} \mathrm{T}$ Cells. The Journal of Experimental Medicine, 204, 1625-1636. http://dx.doi.org/10.1084/jem.20070322

[51] Day, C., Kaufmann, D., Kiepiela, P., Brown, J., Moodley, E., Reddy, S., et al. (2006) PD-1 Expression on HIV-Specific T Cells Is Associated with T-Cell Exhaustion and Disease Progression. Nature, 443, 350-354. http://dx.doi.org/10.1038/nature05115

[52] Jones, R., Ndhlovu, L., Barbour, J., Sheth, P., Jha, A., Long, B., et al. (2008) Tim-3 Expression Defines a Novel Population of Dysfunctional T Cells with Highly Elevated Frequencies in Progressive HIV-1 Infection. The Journal of Experimental Medicine, 205, 2763-2779. http://dx.doi.org/10.1084/jem.20081398

[53] Trautmann, L., Janbazian, L., Chomont, N., Said, E., Gimmig, S., Bessette, B., et al. (2006) Upregulation of PD-1 Expression on HIV-Specific CD8 ${ }^{+}$T Cells Leads to Reversible Immune Dysfunction. Nature Medicine, 12, 1198-1202. http://dx.doi.org/10.1038/nm1482

[54] Brenchley, J.M. (2002) Expression of CD57 Defines Replicative Senescence and Antigen-Induced Apoptotic Death of CD8 ${ }^{+}$T Cells. Blood, 101, 2711-2720. http://dx.doi.org/10.1182/blood-2002-07-2103

[55] Kaech, S.M., Hemby, S., Kersh, E. and Ahmed, R. (2002) Molecular and Functional Profiling of Memory CD8 T Cell Differentiation. Cell, 111, 837-851. http://dx.doi.org/10.1016/S0092-8674(02)01139-X

[56] Blackburn, S., Shin, H., Haining, W., Zou, T., Workman, C., Polley, A., et al. (2009) Coregulation of CD8 ${ }^{+}$T Cell Exhaustion by Multiple Inhibitory Receptors during Chronic Viral Infection. Nature Immunology, 10, 29-37. http://dx.doi.org/10.1038/ni.1679 
Scientific Research Publishing (SCIRP) is one of the largest Open Access journal publishers. It is currently publishing more than 200 open access, online, peer-reviewed journals covering a wide range of academic disciplines. SCIRP serves the worldwide academic communities and contributes to the progress and application of science with its publication.

Other selected journals from SCIRP are listed as below. Submit your manuscript to us via either submit@scirp.org or Online Submission Portal.
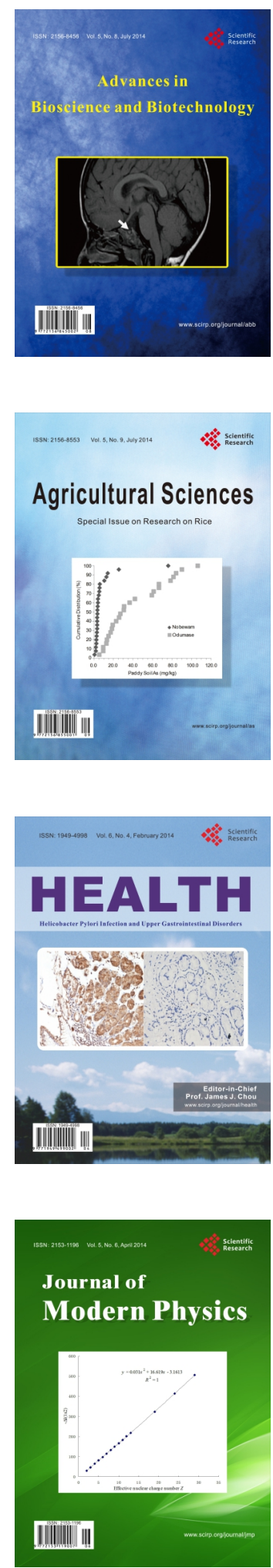
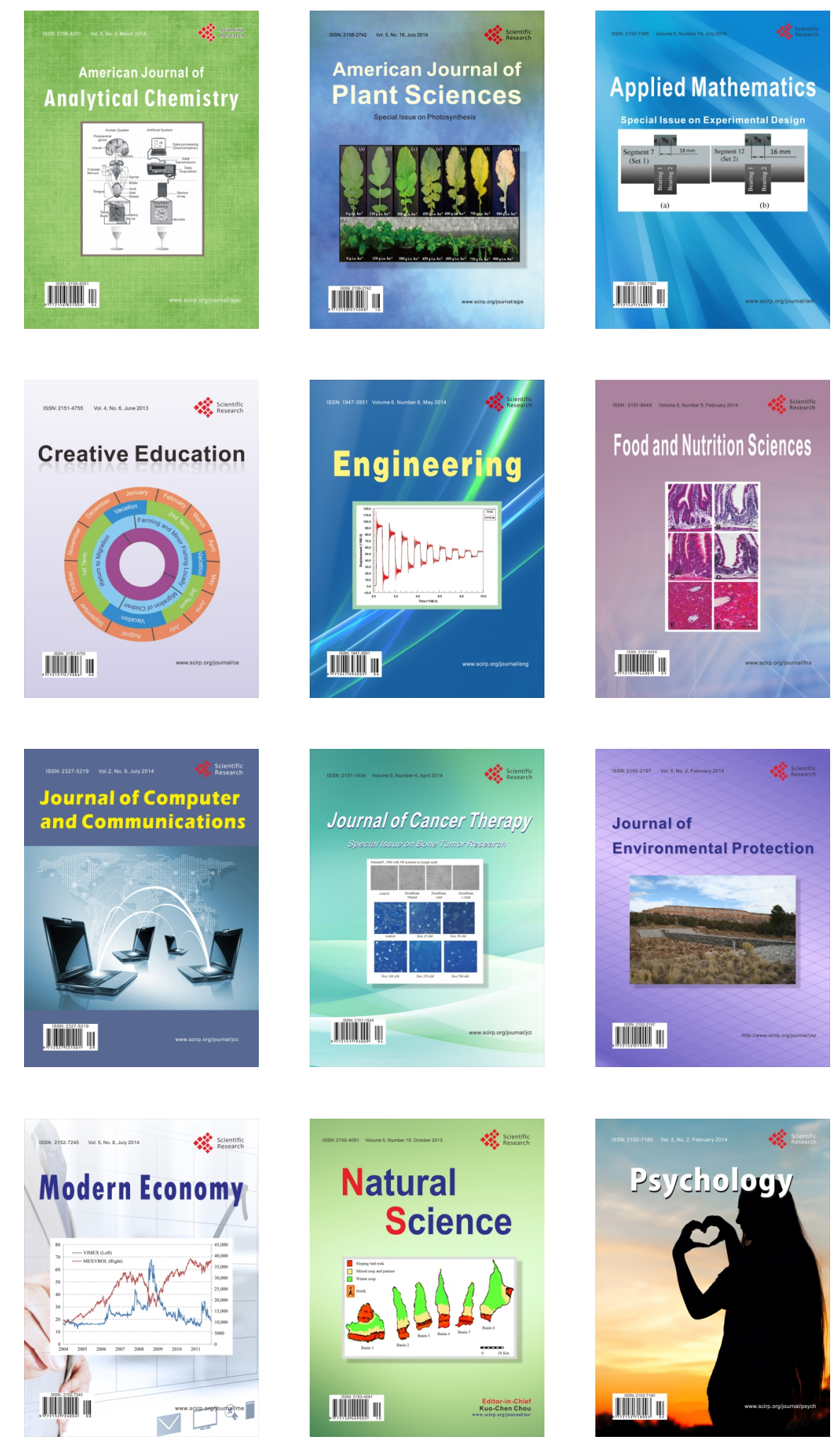